\title{
In vitro Propagation of Phytoplasma-Free Strawberry Plants and Molecular Characterization of the Pathogen
}

\author{
Samah A. Mokbel ${ }^{1}$ and Ahmed A. Kheder ${ }^{2}$
}

${ }^{I}$ Plant tissue culture laboratory, Virus and Phytoplasma Research Department, Plant Pathology Research Institute, Agricultural Research Center (ARC), 12619, Giza, Egypt.

2Molecular biology laboratory, Virus and Phytoplasma Research Department, Plant Pathology Research Institute, Agricultural Research Center (ARC), 12619, Giza, Egypt

\author{
Received: 30 May 2020/ Accepted 22 July 2020 / Publication date: 10 August 2020
}

\begin{abstract}
Multiplication of strawberry plants in tissue culture has advantages as reduced exposure to many insects and several various diseases. During 2019 growing season, strawberry (Fragaria x ananassa Duchesne cv. Festival) plants showing phyllody fruit symptoms, in which petals and sepals become leaf-like, were detected in planting fields in Ismailia governorate, Egypt. Phytoplasma associated with phyllody of fruit in strawberry plants was detected using phytoplasma universal primers, accurately identified at the molecular level, and the DNA sequence has been deposited in GenBank under accession number MT757900 with Isolate name SAMA. DNA from all symptomatic plants yielded PCR products of 1278 bp, whereas DNA from asymptomatic plants collected in the field yielded no products. The phylogenetic analysis of the 16S rDNA sequence of SAMA-isolate indicated that the 16S rDNA gene shared $100 \%$ identity with StrawbPhF-isolate classified in a group 16SrI (AY102275) that belonged to new subgroup R. Meristems (0.1-0.3 $\mathrm{mm}$ in size) were excised from the terminal and axillary buds of the strawberry-runners and then cultured on hormone-free medium. The two sizes $(0.2 \mathrm{~mm}$ and $0.3 \mathrm{~mm})$ of meristem had pronounced effects on the phytoplasma elimination (100\%), and survival rates (66.6 $\%$ and $90 \%$, respectively), but the smaller size of meristem had a deleterious effect to survival rate $(0 \%)$. After approximately seven months and a half, rooted plantlets raised from meristem culture were confirmed for phytoplasma-free by a nested PCR assay. Therefore, the production of strawberry plantlets that needs no examination for their phytoplasma infection could be expected by applying the meristem culture method.
\end{abstract}

Keywords: Strawberry, Phyllody, Phytoplasma, 16Sr RNA, Sequence, Meristem culture.

\section{Introduction}

Strawberry (Fragaria $\mathrm{x}$ ananassa Duch. cv. Festival) is a unique and delicious fruit crop that belongs to the rose family (Rosaceae), in the subfamily Rosoideae, and monophyletic genus Fragaria (Nellist et al., 2019). Also, they are a rich source of vitamins and minerals (Naing et al., 2019). In 2018, the annual production estimated to be about 362639 tons in the cultivated area of about 8800 hectares, and Egypt ranked as the fifth country in the world on strawberry production after China, USA, Mexico, and Turkey (FAO, 2019).

Phytoplasmas, class Mollicutes, genus Candidatus Phytoplasma, are bacterial plant pathogens, consisting of more than 50 phylogenetic groups (Olivier et al., 2009). Strawberry plants have been reported to be infected by phytoplasmas belonging to six 16Sr groups: 16SrI, 16SrIII, 16SrVI, 16SrVII, 16SrXII and 16SrXIII (Harrison et al., 1997; Jomantiene et al., 1999; Padovan et al., 2000; Jomantiene et al., 2002 and Fernandez et al., 2013). Moreover, new 16SrI-K, 16SrI-R, and 16SrXIII-K phytoplasma subgroups were associated with strawberry phyllody in the USA and Chile (Jomantiene et al., 1999, 2002 and Cui et al., 2019).

Strawberry plants associated with the presence of phytoplasmas typically exhibit many symptoms that are suggestive of disturbances in the normal balance of plant hormones. Plant symptoms in addition to phyllody (flowers turned into leafy shoots or their petals into green) may include chlorosis, virescence, stunting, and crown proliferation (Jomantiene et al., 2001, 2002 and Sofy, 2015). Since the

Corresponding Author: Samah A. Mokbel, Plant tissue culture laboratory, Virus and Phytoplasma Research Department, Plant Pathology Research Institute, Agricultural Research Center (ARC), 12619, Giza, Egypt. E-mail: dr.samahmokbel@gmail.com ORCID ID https://orcid.org/0000-0001-9374-9552 
presence of distinctive symptoms on fruits, damages caused by a phytoplasma can directly affect crop loss with reduced marketable yield, as well as causes indirect losses through the cost of prevention and treatment.

A technique of plant tissue culture in vitro appears as an applicable and efficient method to propagate the strawberry plants exposed to many pathogens and insects, which allows for rapid multiplication and preserving the genetics of pathogen-free plants under strictly controlled conditions. The advantages of tissue culture beyond preserving genetics are the opportunity to produce many more daughter plants in a short time than conventionally propagated plants. Besides, the micro-propagated strawberry plants considered comparatively better in different characters such as crown size, the number of runners, flowering time, and yield of strawberries than conventionally propagated plants (Karhu and Hakala, 2007). However, problems with different types, especially a hyper-flowering trait, have been reported (Boxus et al., 2000). Limiting the number of subcultures and reducing hormones in the media could treat hyper-flowering problems (Boxus et al., 2000).

In particular, pathogen elimination by meristem culture considered one of the efficient methods for the production of various-pathogen-free plants (Faccioli and Marani, 1998). Because of the inability of many pathogens to invade the meristematic region due to the absence of differentiated conducting vascular tissues and the presence of the high endogenous auxin levels in apical meristems as well as the multiplication of meristem cells is faster than the replication of plant pathogens. Numerous in vitro methods were also tested for phytoplasma elimination, from thermotherapy by hot water or hot air to chemotherapy with antibiotics, which showed some successful levels in the pathogen elimination process (Laimer and Bertaccini, 2019). However, thermotherapy or hot water therapy may induce genetic variations or affect the vitality of the propagation materials (Mannini, 2007 and Acquadro et al., 2010). Further, among the many chemical compounds tested, tetracycline or chloramphenicol reduced the phytoplasma disease symptoms, however in all cases, the associated symptoms reoccurred with stopped these treatments (Laimer and Bertaccini, 2019). However, within the production of pathogen-free plants by using meristem culture, many obstacles and challenges as meristem size and chances of plant survival have arisen.

Therefore, the objectives of the present study were to identify and characterize phytoplasma associated with the observed symptomatology in strawberries grown in Ismailia governorate well as to evaluate the efficacy of meristems of different sizes $(0.1 \mathrm{~mm}, 0.2 \mathrm{~mm}$, and $0.3 \mathrm{~mm})$ in the elimination of phytoplasma and on the percentages of explants survival.

\section{Materials and Methods}

\section{Plant materials}

During 2019, strawberry plants exhibiting structural abnormalities (such as flowers turned into leafy shoots or their petals into the green) were observed in planting fields in the Ismailia governorate. Since the symptoms were suggestive of phytoplasma infection, plants were assayed for the presence of phytoplasma by PCR amplification of the $16 \mathrm{~S}$ rDNA gene sequence as the procedure mentioned later.

\section{Plant tissue culture and phytoplasma elimination}

\subsection{Establishment of aseptic explants}

Runner chains (of 10-15 cm) were collected from field-grown infected strawberry plants. These were transferred to the laboratory and then washed with running water for $60 \mathrm{~min}$. Runners were cut up into smaller sizes (about 1-2 cm, Fig. 1) and then dipped in an antioxidant solution of $150 \mathrm{mg} / 1 \mathrm{of}$ ascorbic and $100 \mathrm{mg} / \mathrm{l}$ citric acids for $10 \mathrm{~min}$ (Mokbel, 2008). These materials were then placed in 20\% commercial Clorox solution for 20 min containing one drop of Tween 20 and rinsed three times in sterile distilled water ( 5 min each). Finally, materials were placed in $70 \%$ ethanol solution for $30 \mathrm{sec}$ under aseptic conditions before applying the meristem culture method.

\subsection{The size effect on phytoplasma-elimination and meristem survival percentages}

After the sterilization process, thirty meristems of each size $(0.1,0.2$, or $0.3 \mathrm{~mm}$ consist of the meristematic dome and one leaf primordial) were dissected and excised from the terminal and axillary buds of the sterilized runners using binocular under aseptic conditions. Meristems were immediately cultured in glass tubes containing the hormone-free MS medium (MS, Murashige and Skoog, 1962) 
with $2.5 \mathrm{~g} / 1$ phytagel (Sigma-Aldrich) and $30 \mathrm{~g} / 1$ sucrose. The $\mathrm{pH}$ of the culture medium was adjusted to 5.8 before adding phytagel. The medium was sterilized by autoclaving for 20 minutes at a temperature of $121^{\circ} \mathrm{C}$, of $1.5 \mathrm{~kg} / \mathrm{cm}^{2}$. Explants were incubated in a growth chamber at $25 \pm 1^{\circ} \mathrm{C}$, under dark conditions for one week (Gomes and Canhoto, 2009) and then transferred to light with a photoperiod of 16 hours light/8 hours' darkness for two months. The number of surviving meristems in each size was expressed relative to the total number of meristems from the date of the meristem establishment, as well as the rate of success in eliminating phytoplasma from sizes-derived shoots was determined using nested-PCR.

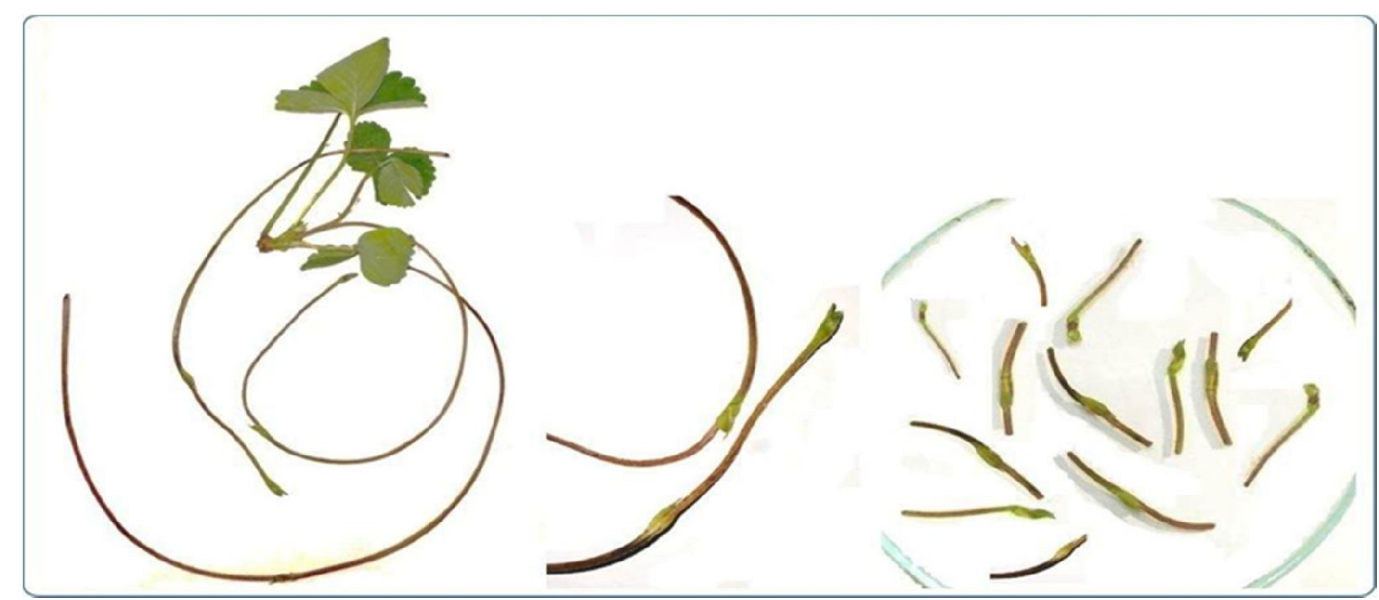

Fig. 1: Strawberry runners from infected plants by phytoplasma associated with phyllody of strawberry fruit and runner tips used as explant sources in meristem culture experiments.

\subsection{In vitro shoot multiplication and root induction}

Phytoplasma-free shoots derived from $0.2 \mathrm{~mm}$ and $0.3 \mathrm{~mm}$ sizes were transferred on modified MS medium with $100 \mathrm{mg} / 1$ Myo-inositol, containing $0.5 \mathrm{mg} / \mathrm{l}$ kinetin (Kn) (Naing et al., 2019). Subcultures of tested-shoots were done every 6 weeks into a fresh medium until the fourth subculture. The developed plantlets from size $0.3 \mathrm{~mm}$ were transferred for 6 weeks onto half-strength rooting medium containing $1.0 \mathrm{mg} / \mathrm{l}$ indole-3-butyric acid (IBA) and $200 \mathrm{mg} / 1$ activated charcoal (AC). Cultures were incubated in a growth chamber at $25^{\circ} \mathrm{C} \pm 1^{\circ} \mathrm{C}$ with a $16 / 8$ photoperiod ( 16 hours of light, 8 hours of darkness). To confirm the elimination of phytoplasma from in vitro grown plantlets, randomly selected samples were tested using nested PCR assay.

\section{Molecular detection and phytoplasma identification}

\subsection{DNA extraction and detection procedures}

Total DNA was extracted from naturally infected strawberry plant leaves as well as the healthy ones and in vitro plantlets of different stages: meristems establishment and root induction, using the extraction method developed by Dellaporta et al. (1983). Nucleic acid was precipitated by adding 2.5 volumes absolute ethanol then collected by centrifugation, washed twice in $70 \%$ ethanol, dried and resuspended in $50 \mu \mathrm{TE}$ tuffer (10 mM Tris, $1 \mathrm{mM}$ EDTA, $\mathrm{pH}$ 8.0). Direct PCR assays were performed using primer pair P1/P7 (Schneider et al., 1995). Three $\mu 1$ of extracted DNA was used in $25 \mu 1$ total PCR reaction mixture contained $10 \mathrm{pmol}$ of each primer; $12.5 \mu 1$ Mangotaq DNA polymerase (Bioline $\mathrm{GmbH}$, Luckenwalde). The product of the direct reaction was diluted 1:10 with nuclease-free water (Promega, USA), and used as a template for nested PCR with primers R16F2n/R16R2 (Deng and Hiruki, 1991). The DNA amplification was started with a denaturation step at $94^{\circ} \mathrm{C}$ for 3 min followed by 35 cycles consisting of denaturation at $94^{\circ} \mathrm{C}$ for $30 \mathrm{Sec}$., annealing at $53^{\circ} \mathrm{C}$ for $1 \mathrm{~min}$ extension at $72^{\circ} \mathrm{C}$ for $2 \mathrm{~min}$, a final extension step was added for $7 \mathrm{~min}$ at $72^{\circ} \mathrm{C}$. Total DNA from Faba bean plants infected with phyllody phytoplasma (ACC. No. LC487858) was used as a positive control. DNA from an asymptomatic strawberry plant collected in the field was used as a negative control. The PCR products were stained with EZ View nucleic acid stain (Biomatik, USA), analyzed by electrophoresis in $1.0 \%$ agarose gel, and then visualized by UV illumination. 


\subsection{Nucleotide sequencing}

The PCR product of the spacer region R16F2n/R16R2 of the phytoplasma genome was gel extracted using Gel/PCR DNA Fragments Extraction Kit (Geneaid, Taiwan). The purified PCR product was directly sequenced using automated DNA sequencing in both directions. The nucleotide sequences were assembled and analyzed using DNAMAN sequence analysis software (Lynnon Corporation, Canada) ver.7. The nucleotide sequence was compared with the corresponding sequences of thirty-two sequences of other phytoplasma isolates from a variety of geographical locations that were deposited in the GenBank.

\section{Results}

\section{Symptoms and detection of phytoplasma}

Samples collected from the Ismailia governorate of naturally infected strawberry plants exhibited phytoplasma-like symptoms and their associated phyllody-disease (Fig.2). Phytoplasma detected in all collected samples of symptomatic strawberry flowers by field visual inspection and PCR-based assays. Total DNA was extracted successfully from naturally infected and healthy strawberry plants as well as from in vitro plantlets and used as a template for direct PCR using the universal primer pair P1/P7 and nested PCR amplification using R16F2n/R16R2, respectively.

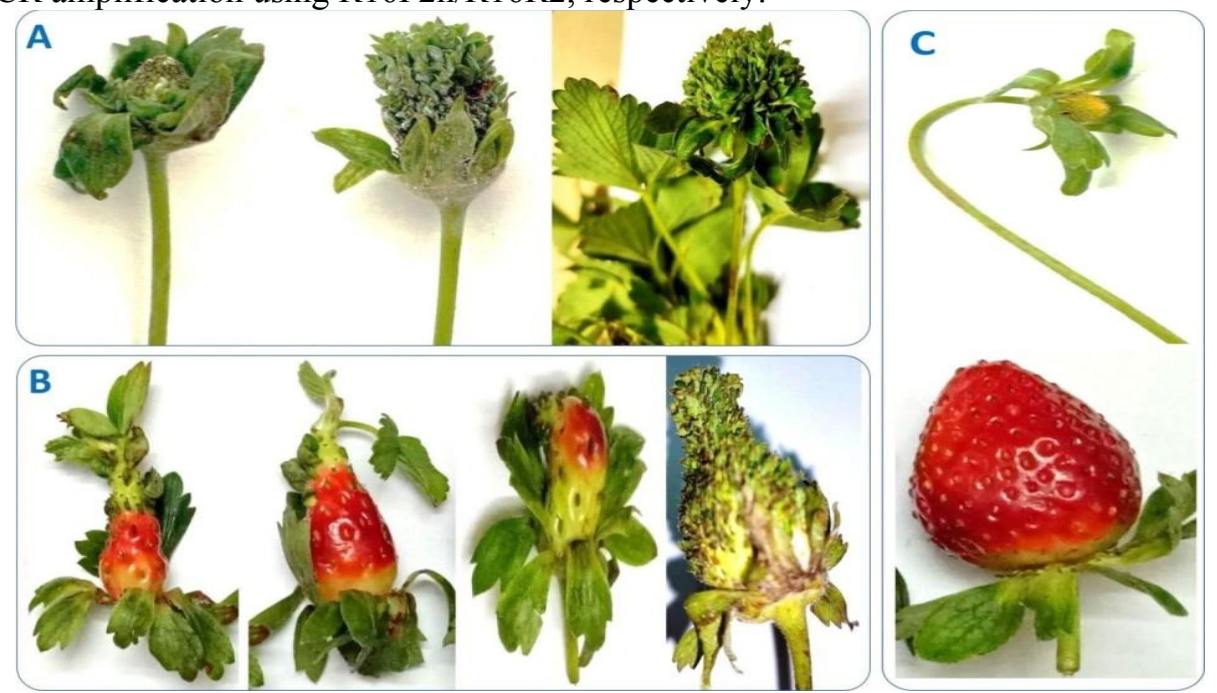

Fig. 2: Symptoms of a phytoplasma associated with phyllody of strawberry fruit at Ismailia governorate. Deformation and abnormal development of floral parts or leaf-like structures replace the flower (A), Deformation of already formed strawberry fruits and fruit discoloration (B), Flower, sepals in a healthy plant, and healthy fruit on the right side (C).

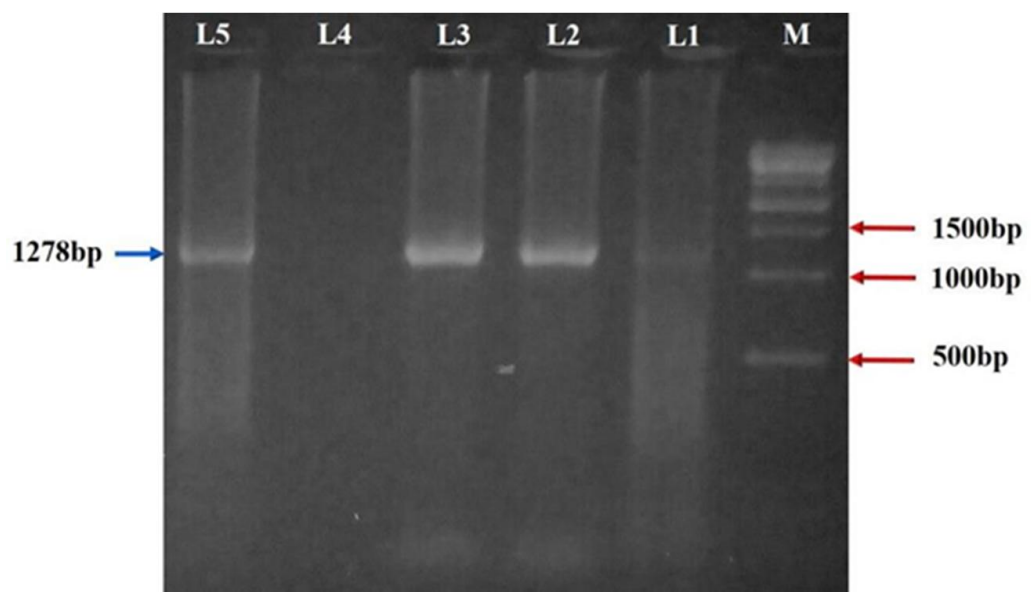

Fig. 3: Agarose gel electrophoresis of PCR products from the 16S rDNA gene of phytoplasma using primers R16F2n and R16R2. L1: Asymptomatic strawberry plant. L2, L3, and L5: Different samples of symptomatic strawberry plants. M: 1Kb DNA Ladder (Biomatic-USA). 
All symptomatic strawberry samples generated amplicons of about $1278 \mathrm{bp}$ when used as a template as a result of the nested PCR amplification using R16F2n/R16R2 (Fig. 3 with lane 4 empty). The same primer pair failed to generate the amplicon in a PCR mixture containing DNA from the asymptomatic samples collected in the field (Fig.3) as well as from all healthy samples of in vitro cultures (Fig. 4).

\section{Effect of meristem size on survival percentages and phytoplasma elimination}

Thirty meristem tips of size $0.1,0.2$, or $0.3 \mathrm{~mm}$ were excised from the terminal and axillary buds of the strawberry plant runners then placed on MS medium without plant growth regulators for two months. In vitro-performance of explants indicated a correlation (positive or negative) between apical shoots formation and size of the meristem tip. At the start of the study, isolation of the $0.1 \mathrm{~mm}$ size was difficult in some plants, resulting in unexpected results, as the apical shoot was not formed $(0 \%)$ over two months. By increasing the size of meristem to 0.2 and $0.3 \mathrm{~mm}$, the efficiency in culture improved considerably, resulting in a notable response in many explants on hormone-free MS medium. Culture of $0.2 \mathrm{~mm}$ tips resulted in $66.6 \%$ survived meristems ( 20 out 30 ), nonetheless, the explants showed slow growth with somewhat weak shoots. The best survival percentage $90 \%$ (27 out of 30 ), was obtained with a size of $0.3 \mathrm{~mm}$ of meristem tips. The larger size $(0.3 \mathrm{~mm})$ was found to be the most appropriate for the maximum establishment and showed a quick change in growth over time. The common point between 2 sizes, 0.2 and $0.3 \mathrm{~mm}$ of meristems, is $100 \%$ of phytoplasma-free shoots, as all the samples were found negative by nested-PCR (Fig.4).

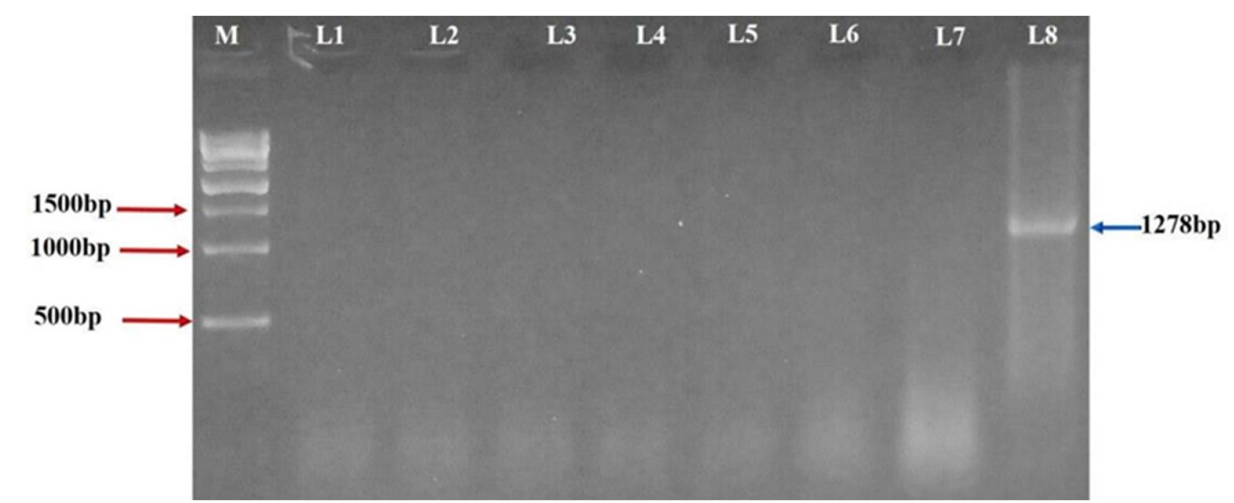

Fig. 4: Agarose gel electrophoresis of PCR products from shoots derived from different sizes of meristems using universal phytoplasma specific primers R16F2n/R16R2. Lanes $1-3$ representing phytoplasma-free strawberry shoots derived from $0.2 \mathrm{~mm}$ meristem size, Lanes 4-6 representing phytoplasma-free strawberry shoots derived from $0.3 \mathrm{~mm}$ meristem size, respectively. Lane 7: Negative control sample. Lane 8: Positive control sample. M: 1Kb DNA Ladder (Biomatic-USA).

The strawberry shoots were then transferred to MS medium supplemented with $0.5 \mathrm{mg} / \mathrm{l} \mathrm{Kn}$, and the micropropagation rate increased gradually during three subcultures. During the fourth successive subculture, the micropropagation rate slightly varied, and the developed shoots from size $0.3 \mathrm{~mm}$ were observed as a more vigorous (Fig.5B) than those originated from $0.2 \mathrm{~mm}$ size (Fig.5A) with high roots on MS media containing $1.0 \mathrm{mg} / 1 \mathrm{IBA}$ and $200 \mathrm{mg} / \mathrm{l} \mathrm{AC} \mathrm{(Fig.5C).} \mathrm{The} \mathrm{developed} \mathrm{shoots} \mathrm{tested} \mathrm{again}$ negative for phytoplasma presence by nested-PCR after approximately six months (Agarose gel not displayed).

\section{Sequence analysis}

The purified PCR products were directly sequenced in both directions and compared with the corresponding sequences of other 32 isolates of phytoplasma from different geographical regions available in GenBank (Fig. 6), the obtained data were assembled with DNAMAN sequence analysis software. The nucleotide sequence was submitted to the GenBank with accession number MT757900 as a strawberry-SAMA isolate. Results of multiple sequence alignment and phylogenetic analyses showed that SAMA-isolate has $100 \%$ similar to Strawberry phyllody fruit phytoplasma (StrawbPhF) from West Virginia State, USA (ACC. No. AY102275). The sequence result also observed that the 
identity was about 99.6\% with little leaf phytoplasma (Darab 1) from Iran (ACC. No. KT992689), about 99.5\% with phytoplasma associated with Eucalyptus yellows and witches' broom from China (ACC. No. AY685054), as well as 98.3\% identity with Candidatus Phytoplasma lycopersici (Santa Cruz) from Bolivia (ACC. No. EF199549). Additional comparisons showed that the nucleotide sequence from SAMA-isolate has similarities from 99.5 to $100 \%$ to phytoplasmas belonging to group $16 \operatorname{SrI}$ (Table 1).

Fig. 5: In 1
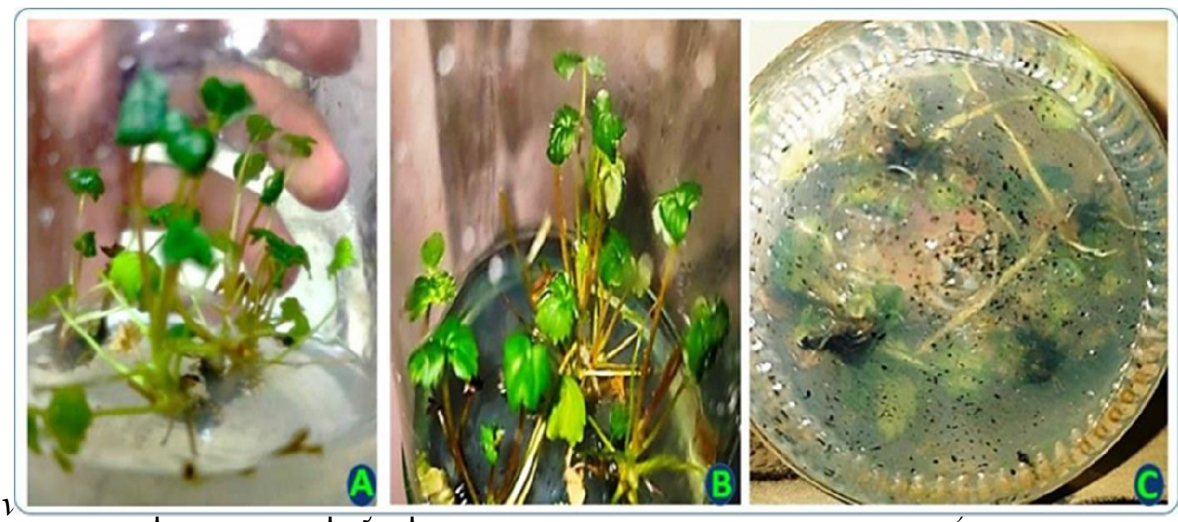

the $0.2 \mathrm{~mm}$ meristem size after four successive subcultures on MS medium containing $0.5 \mathrm{mg} / \mathrm{l}$ $\mathrm{Kn}$. B) Induction of shoots from the $0.3 \mathrm{~mm}$ meristem size after four successive subcultures on the same medium. C) Induction of roots from the $0.3 \mathrm{~mm}$ meristem-derived plants after 6 weeks of culture on the half-strength rooting medium containing $1.0 \mathrm{mg} / 1 \mathrm{IBA}$ and $200 \mathrm{mg} / \mathrm{l} \mathrm{AC}$.

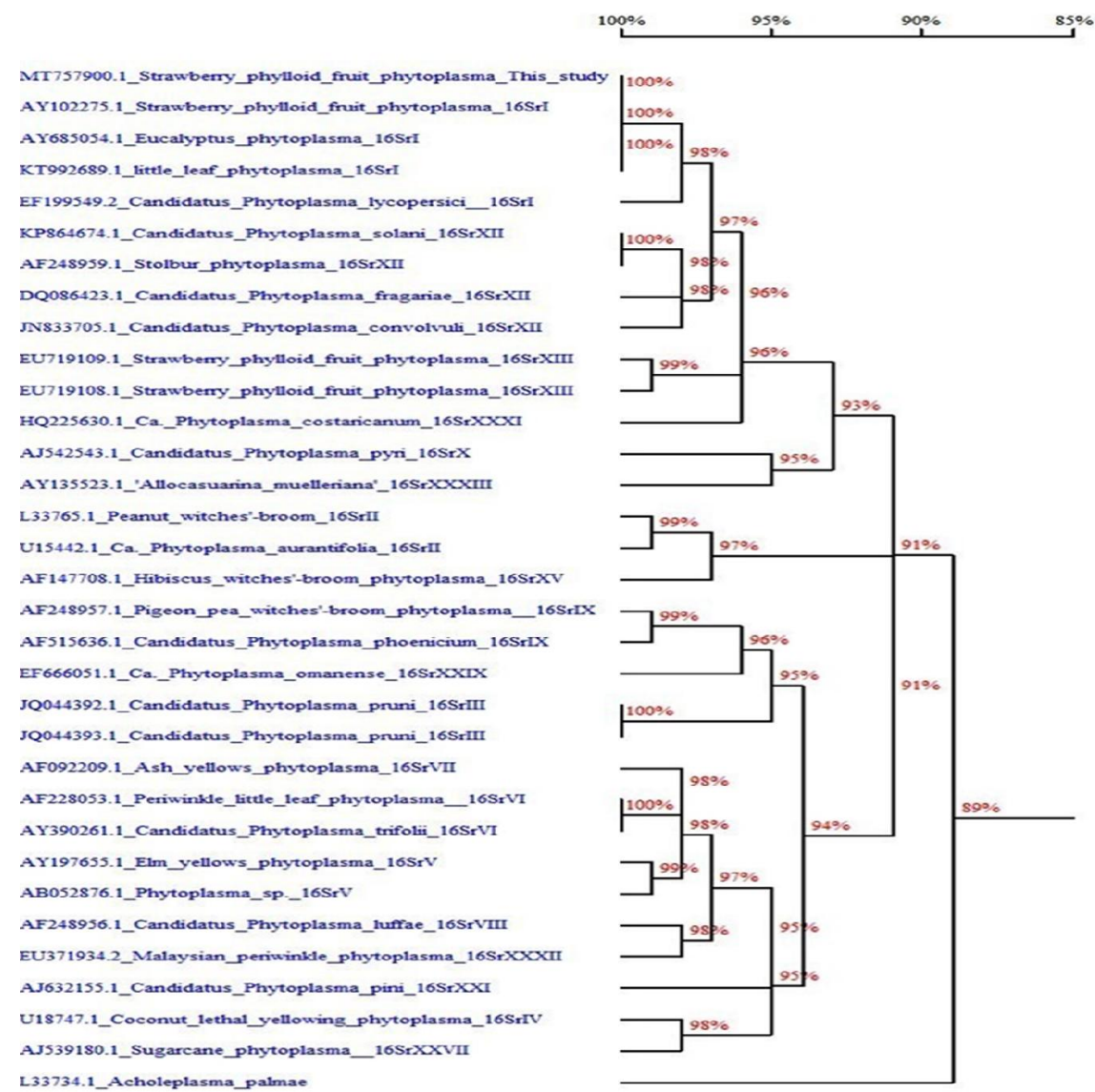

Fig. 6: Phylogenetic tree constructed using DNAMAN ver.7 based on the 16S rRNA gene of 32 phytoplasma isolates obtained from GenBank and the phytoplasma isolate (MT757900) in the present study. Acholeplasma Palmae (133734) was used as an outgroup to root the tree. 
Table 1: Comparison of the nucleotide sequences of the 16S rRNA gene of phytoplasma isolated in the present study (SAMA-isolate) with the corresponding sequences of phytoplasma isolates from other countries.

\begin{tabular}{|c|c|c|c|c|c|}
\hline $\begin{array}{c}\text { Isolate } \\
\text { name }\end{array}$ & $\begin{array}{l}\text { Accession } \\
\text { number }\end{array}$ & Country & Host plant & Group & $\begin{array}{c}\% \\
\text { Id }^{1} \\
\end{array}$ \\
\hline SAMA & MT757900 & Egypt & Fragaria ananassa & $16 \mathrm{SrI}$ & 100 \\
\hline StrawbPhF & AY102275 & USA & Fragaria ananassa & $16 \mathrm{SrI}$ & 100 \\
\hline Darab 1 & KT992689 & Iran & Eucalyptus sp. & $16 \mathrm{SrI}$ & 99.6 \\
\hline $\mathrm{NA}^{2}$ & AY685054 & China & Eucalyptus sp. & $16 \mathrm{SrI}$ & 99.5 \\
\hline Santa Cruz & EF199549 & Bolivia & Lycopersicon esculentum & $16 \mathrm{SrI}$ & 98.3 \\
\hline WBDL & U15442 & Oman & Catharantus roseus & $16 \mathrm{SrII}$ & 90.8 \\
\hline $\mathrm{SPWB}^{3}$ & L33765 & Taiwan & Catharantus roseus & $16 \mathrm{SrII}$ & 90.5 \\
\hline PX11Ct1 & JQ044392 & USA & Prunus persica & $16 \mathrm{SrIII}$ & 91.4 \\
\hline PX11Ct1 & JQ044393 & USA & Prunus persica & 16SrIII & 91.5 \\
\hline MLO & U18747 & USA & Veitchia merrillii & $16 \mathrm{SrIV}$ & 91.1 \\
\hline EY1 & AY197655 & USA & Ulmus americana & $16 \mathrm{SrV}$ & 91.1 \\
\hline JWB-G1 & AB052876 & Japan & Ziziphus jujuba & $16 \mathrm{SrV}$ & 90.9 \\
\hline $\mathrm{CP}$ & AY390261 & Canada & Trifolium hybridum & $16 \mathrm{SrVI}$ & 91.1 \\
\hline PLL-Bd & AF228053 & Bangladesh & Catharantus roseus & $16 \mathrm{SrVI}$ & 90.8 \\
\hline AshY1 & AF092209 & USA & Fraxinus americana & $16 \mathrm{SrVII}$ & 90.8 \\
\hline LfWB & AF248956 & Taiwan & Luffa acutangula & 16SrVIII & 91.2 \\
\hline PPWB & AF248957 & USA & Cajanus cajan & $16 \mathrm{SrIX}$ & 90.2 \\
\hline A4 & AF515636 & Lebanon & Prunus dulcis & $16 \mathrm{SrIX}$ & 89.9 \\
\hline PD1 & AJ542543 & Germany & Pyrus communis & $16 \mathrm{SrX}$ & 93.9 \\
\hline StrawY & DQ086423 & Lithuania & Fragaria ananassa & 16SrXII & 97.6 \\
\hline BY-S57/11 & JN833705 & Serbia & Convolvulus arvensis & 16SrXII & 97.2 \\
\hline Rus-907 & KP864674 & Russia & Solanum tuberosum & 16SrXII & 96.5 \\
\hline $\mathrm{STOL}^{3}$ & AF248959 & USA & Vitis vinifera & $16 \mathrm{SrXII}$ & 96.1 \\
\hline SFP-Br3 & EU719109 & Brazil & Fragaria ananassa & $16 \mathrm{SrXIII}$ & 96.4 \\
\hline SFP-Br2 & EU719108 & Brazil & Fragaria ananassa & $16 \mathrm{SrXIII}$ & 96.3 \\
\hline HibWB26 & AF147708 & USA & Hibiscus rosa-sinensis & $16 \mathrm{SrXV}$ & 90.5 \\
\hline Pin127S & AJ632155 & Spain & Pinus halepensis & $16 \mathrm{SrXXI}$ & 90.7 \\
\hline Mauritius & AJ539180 & Mauritius & Saccharum officinarum & 16SrXXVII & 92.8 \\
\hline IM-1 & EF666051 & Oman & Cassia italica & 16SrXXIX & 89.8 \\
\hline SoyST1c1 & HQ225630 & Costa Rica & Glycine $\max$ & 16SrXXXI & 96.2 \\
\hline MaPV & EU371934 & Malaysia & Catharantus roseus & 16SrXXXII & 91.5 \\
\hline $\mathrm{NA}^{2}$ & AY135523 & Australia & Allocasuarina muelleriana & $16 \mathrm{SrXXXIII}$ & 92.4 \\
\hline ATCCJ233 & L33734 & USA & Cocos nucifera & & 90.7 \\
\hline
\end{tabular}

$\mathrm{Id}^{1}$ : Identity and the highest identity value indicated in bold. $\mathrm{NA}^{2}$ : Not available. References ${ }^{3}$ for isolates SPWB and STOL are Gundersen et al., 1994 and Davis and Dally, 2001, respectively.

Phytoplasma-isolates ${ }^{1}$ can be directly queried with any protein sequence in the GenBank database by accession number pressing. $\mathrm{Id}^{2}$ : Identity and the highest identity value indicated in bold. $\mathrm{NA}^{3}$ : Not available. References ${ }^{4}$ for isolates SPWB and STOL are Gundersen et al., 1994 and Davis and Dally, 2001, respectively.

\section{Discussion}

Among the plant diseases, phyllody disease, caused by a phytoplasma, is one of the major problems in strawberry cultivation (Jomantiene et al., 2001). During 2019, the fresh strawberry plants cultivated in the open fields (Ismailia governorate) showed typical symptoms of disease or the abnormal development of floral parts in leafy structures, and their petals turned into the green. These symptoms are similar to those described by Sofy, (2015). The major cause of pathogen-induced abnormal plant development is the disruption of signaling mechanisms mediated by plant hormones such as jasmonates, auxin, abscisic acid, and gibberellins (Grant and Jones, 2009). Recently, a phytoplasma SAP54 effector was reported to cause morphological changes in the infected plants' flower organ development (MacLean et al., 2011). The present investigation was conducted because of the absence of any recorded sequencing data of phytoplasma DNA associated with phyllody of strawberry fruit from Egypt on the GenBank as well as to eliminate phytoplasma from infected strawberry Festival-variety by meristem 
culture method. According to the distinct symptoms, the collected leaf samples tested positive for phytoplasma by PCR assays. The DNA was extracted from symptomatic strawberry plants to detect phytoplasma using nested-PCR, that were performed by preliminary amplification using a universal primer pair P1/P7 (Schneider et al., 1995) followed by second amplification using a second primer pair R16F2n/R16R2 (Deng and Hiruki, 1991).

The final PCR product (1278 bp) was sequenced and deposited in GenBank (ACC. No: MT757900). Sequence comparison and phylogenetic analysis (DNAMAN 7.0) of the 16S rDNA sequence of SAMA-isolate (MT757900) indicated that this gene shared $100 \%$ identity with StrawbPhFisolate classified in a group 16SrI (AY102275) that belonged to new subgroup R (Jomantiene et al., 2002). Thus, the 16S rRNA subgroup was assumed, as a new 16SrI-R subgroup (Jomantiene et al., 2002), based on percent similarity between the isolates (SAMA and StrawbPhF) and the taxonomy of the reference strains for phytoplasmas described either at the 'Candidatus' level or at the 16S rDNA group/subgroup level (Duduk and Bertaccini, 2011). However, future studies on this phytoplasma strain (SAMA) are needed to provide accurate information on the classification of phytoplasma of strawberry phyllody at the $16 \mathrm{~S}$ rDNA subgroup level.

Concerning the effect of meristem size on meristem survival percentages and phytoplasmaelimination, runner tips were collected from field-grown plants. These were surface sterilized, and then various sizes of meristems $(0.1,0.2$, and $0.3 \mathrm{~mm})$ were excised. The unexpected result in the present study was repeated with the smallest size of the meristems $(0.1 \mathrm{~mm})$ among all sizes used. It has been found to affect the explant survival with the lowest rates $(0 \%)$ during in vitro culture establishment and was hence not tested for the presence or absence of phytoplasma. Generally, apical meristem damage may occur as a result of slow dealing with plant material and rapid dehydration under the flow of air within the tissue culture hood, or due to the release of phenolic compounds from the tissues into the culture medium. The third reason for meristem damage, if the dome is damaged excessively by contact with the dissecting instruments, chances of survival are reduced (Love et al., 1987). Accordingly, the extremely smaller pieces of any meristem less than $0.2 \mathrm{~mm}$ will not grow. In contrast, the results indicate that the largest size $(0.3 \mathrm{~mm})$ of meristem provides the high capability of surviving $(90 \%)$ as well as the multiplication capability of the strawberry plantlets among subcultures.

In the present study, nested-PCR tests confirmed the presence of phytoplasma in the leaves of the naturally infected strawberry plants, and otherwise in all meristems with 0.2 and $0.3 \mathrm{~mm}$ size excised from fully developed runners of selected diseased strawberry plants. The preliminary results of phytoplasma free plants were obtained after two months from the establishment of meristems as well as after seven months and a half from in vitro root induction on the medium containing $1.0 \mathrm{mg} / \mathrm{l} \mathrm{IBA}$ and $200 \mathrm{mg} / \mathrm{l} \mathrm{AC}$.

The discrepancy of phytoplasma result tests confirms the elimination of the pathogen using meristem culture. Thus, phytoplasma-free plants from the infected in vitro shoots could be obtained alone by meristem-culture based methods because its active cell division reduces the differentiation of vascular tissues. Laimer and Bertaccini, 2019 reported that the meristem tip facilitates the production of phytoplasma-free tissue cultures due to the absence of vascular elements in the meristematic region that may effectively prevent the transport of phytoplasma inside plants.

As an effective technique also for viruses, meristem culture method using meristems of size 0.2 $\mathrm{mm}$ or $0.3 \mathrm{~mm}$ has been described widely to eliminating different viruses, such as Cucumber mosaic virus, Indian citrus ringspot virus, Tomato aspermy virus, and Tomato spotted wilt virus (Verma et al., 2004; Singh et al., 2008; Kumar et al., 2009 and AlKhazindar, 2015). Also, Baruch and Quak, (1966) used meristem culture alone for the elimination of Iris mosaic virus from iris plants. Moreover, Whitehouse et al. (2011) confirmed the suitability of meristem culture using sizes ranged from 0.2 to $0.5 \mathrm{~mm}$ for the production of strawberry plants free from crown rot pathogens. Furthermore, some viral diseases of strawberry can be controlled by meristem culture including the viruses that cannot be eliminated by heat treatment (Smith et al., 1970). Over 30 viruses affect strawberries and some of which may not cause obvious symptoms in the fields (Martin and Tzanetakis, 2006). Finally, the addition of $\mathrm{Kn}(0.5 \mathrm{mg} / \mathrm{l})$ in the culture media improved the subsequent in vitro multiplication, suggesting that the use of this growth regulator is a suitable media component in the multiplication of this species (Naing et al., 2019). Similar results were reported in roots induction of different cultivars of strawberry on MS media supplemented with IBA $1.0 \mathrm{mg} / 1$ and charcoal $200 \mathrm{mg} / 1$ or without (Kaur et al., 2005 and Sakila et al., 2007). Besides, in Fragaria sp., Jadwiga et al., (2003) found that plants derived from in vitro 
propagation behaved better under field conditions and produced more leaves, stolons, and flowers than those propagated by stolons.

\section{Conclusion}

The results confirmed the suitability and reliability of the meristem culture of different sizes $(0.2$ $\mathrm{mm}$ and $0.3 \mathrm{~mm}$ ) and subsequent micropropagation of $F$. ananassa for the production of strawberry plants free from phytoplasma. The overall results of this study showed that size $(0.3 \mathrm{~mm})$ of the meristem tip represents a better length than $0.2 \mathrm{~mm}$ to enhance the rate of meristem surviving $(90 \%)$. The nucleotide sequence determined in this study was submitted to the gene bank with the accession number "MT757900". A 1278 bp sequence of the 16S rRNA gene from phytoplasma associated with phyllody of strawberry fruit (SAMA-isolate) showed 100\% homology with the 16S rRNA gene from strawberry phyllody phytoplasma from West Virginia State, USA (StrawbPhF-isolate). Results confirmed that phytoplasma belongs to group $16 \mathrm{SrI}$, and it is more likely that it belongs to the subgroup I-R.

\section{References}

Acquadro, A., M.A. Papanice, S. Lanteri, G. Bottalico, E. Portis, A. Campanale, M.M. Finetti-Sialer, T. Mascia, P. Sumerano and D. Gallitelli, 2010. Production and fingerprinting of virus-free clones in a reflowering globe artichoke. Plant Cell Tissue Organ Cult., 100: 329-337.

AlKhazindar, M., 2015. Elimination of Tomato spotted wilt virus (genus Tospovirus) from infected tomato plants by meristem tip culture. Egypt. J. Bot., 55(1): 149-159.

Baruch, E.R. and F. Quak, 1966. Virus-free plants of iris 'Wedgwood' obtained by meristem culture. Neth. J. Pl. Path., 72: 270-273.

Boxus, P.H., A. Jemmali, J.M. Terzi and O. Arezki, 2000. Drift in genetic stability in micropropagation: The case of strawberry. Acta Hort., 530:155-162.

Cui, W., N. Quiroga, S.T. Curkovic, A. Zamorano and N. Fiore, 2019. Detection and identification of 16SrXIII-F and a novel 16SrXIII phytoplasma subgroups associated with strawberry phyllody in Chile. Eur. J. Plant Pathol.,155: 1039-1046. https://doi.org/10.1007/s10658-019-01808-w.

Davis, R.E. and E.L. Dally, 2001. Revised subgroup classification of group 16SrV phytoplasmas and placement of flavescence dorée-associated phytoplasmas in two distinct subgroups. Plant Dis., 85:790-797.

Dellaporta, S.L., J. Wood and J.B. Hicks, 1983. A plant DNA minipreparation: version II. Plant Mol. Biol. Report., 19-21.

Deng, S. and C. Hiruki, 1991. Amplification of 16S rRNA genes from culturable and nonculturable mollicutes. J. Microbiol. Methods, 14: 53-61.

Duduk, B. and A. Bertaccini, 2011. Phytoplasma classification: Taxonomy based on 16S ribosomal gene, is it enough? Phytopathogenic Mollicutes, 1 (1): 3-13.

Faccioli, G. and F. Marani, 1998. Virus elimination by meristem tip culture and tip micro grafting. In: Hadidi, A. Khetarpal. R.F. and Koganzawa, H. (Eds.) plant virus diseases control. APS Press, St Paul, Minnesota, USA. , 346-380.

FAO, 2019. Food and Agricultural Organization of the United Nations: The data set "Strawberry, production quantity (Tons)", and Area harvested (Hectare), for Egypt contains data from 2018. http://www.fao.org/faostat/en/\#data/QC/visualize.

Fernandez, F.D., V.C. Conci, D.S. Kirschbaum and L.R. Conci, 2013. Molecular characterization of a phytoplasma of the ash yellows group occurring in strawberry (Fragaria $\mathrm{x}$ ananassa Duch.) plants in Argentina. Eur. J. Plant Pathol., 135:1-4.

Gomes, F. and J.M. Canhoto, 2009. Micropropagation of strawberry tree (Arbutus unedo L.) from adult plants. In Vitro Cell. Dev. Biol. Plant, 45: 72-82.

Grant, M.R. and J.D.G. Jones, 2009. Hormone (dis) harmony moulds plant health and disease. Sci., 324: $750-752$.

Gundersen, D.E., I.M. Lee, S.A. Rehner, R.E. Davis and D.T. Kingsbury, 1994. Phylogeny of mycoplasma like organisms (phytoplasmas): a basis for their classification. J. Bacteriol., 176 (17): 5244-5254. 
Harrison, N.A., D.E. Legard, R. Di Bonito and P.A. Richardson, 1997. Detection and differentiation of phytoplasmas associated with diseases of strawberry in Florida. Plant Dis., 81: 230.

Jadwiga, I., J. Czernas, J. Gawronski and J. Hortynski, 2003. Suitability of strawberry (Fragaria x ananassa Duch.) microplants to the field cultivation. J. Food Agric. Environ. 1:190-3.

Jomantiene, R., J.L. Maas, E.L. Dally and R.E. Davis, 1999. First report of clover yellow edge and STRAWB2 phytoplasmas in strawberry in Maryland. Plant Dis., 83:1072.

Jomantiene, R., J.L. Maas, F. Takeda and R.E. Davis, 2002. Molecular identification and classification of strawberry phylloid fruit phytoplasma in group 16SrI, new subgroup R. Plant Dis., 86(8):920.

Jomantiene, R., J.L. Maas, R.E. Davis and E.L. Dally, 2001. Molecular identification and classification of a phytoplasma associated with phyllody of strawberry fruit in Maryland. 85(3): 335.2 - 335.2.

Karhu, C. and A. Hakala, 2007. Micropropagated strawberries on the field. Acta Hort., 567:321-324.

Kaur, R., H. Gautam and D.R. Sharma, 2005. A low cost strategy for micropropagation of strawberry $($ Fragaria $\times$ ananassa Duch.) cv. Chandler. Acta. Hort. 696: 129-133.

Kumar, S.S., M.S. Khan, S.K. Raj and A.K. Sharma, 2009. Elimination of mixed infection of Cucumber mosaic and Tomato aspermy virus from Chrysanthemum morifolium Ramat. cv. Pooja by shoot meristem culture. Sci. Hort., 119: 108-112.

Laimer M. and A. Bertaccini, 2019. Phytoplasma elimination from perennial horticultural crops. In: Bertaccini A., Weintraub P., Rao G., Mori N. (eds) Phytoplasmas: Plant pathogenic bacteria-II. Springer, Singapore. https://doi.org/10.1007/978-981-13-2832-9_9.

Love, S.L., B.B. Rhodes and J.W. Moyer, 1987. Meristem-tip culture and virus indexing of Sweet Potatoes: Potential problems - Troubleshooting death of excised meristem-tips. IBPGR, the International Board for Plant Genetic Resources, Rome, Italy.

MacLean, A.M., A. Sugio, O.V. Makarova, K.C. Findlay, V.M. Grieve, R. Tóth, M. Nicolaisen and S.A. Hogenhout, 2011. Phytoplasma effector SAP54 induces indeterminate leaf-like flower development in Arabidopsis plants. Plant Physiol. 157: 831-841.

Mannini, F., 2007. Hot water treatment and field coverage of mother plant vineyards to prevent propagation material from phytoplasma infections. Bul. Insectol., 60: 311-312.

Martin, R.R. and I. Tzanetakis, 2006. Characterization and recent advances in detection of strawberry viruses. Plant Dis., 90(4): 384-396.

Mokbel, S.A., 2008. Studies on Prunus Necrotic Ringspot virus affecting some species of the Family Rosaceae. Ph.D. Thesis, Plant Pathology Department, Faculty of Agriculture, Cairo University. $125 \mathrm{pp}$.

Murashige, T. and F. Skoog, 1962. A revised medium for rapid growth and bioassays with tobacco tissue culture. Physiol. Plant, 15: 473-497.

Naing, A.H., S.H. Kim, M.Y. Chung, S.K. Park and C.K. Kim, 2019. In vitro propagation method for production of morphologically and genetically stable plants of different strawberry cultivars. Plant Methods, 15:36. https://doi.org/10.1186/s13007-019-0421-0.

Nellist, C.F., R.J. Vickerstaff, M.K. Sobczyk, C.M. Montes, F.M. Wilson, D.W. Simpson, A.B. Whitehouse and R.J. Harrison, 2019. Quantitative trait loci controlling Phytophthora cactorum resistance in the cultivated octoploid strawberry (Fragaria $\times$ ananassa). Hort. Res., 6:60. https://doi.org/10.1038/s41438-019-0136-4.

Olivier, C.Y., D.T. Lowery and L.W. Stobbs, 2009. Phytoplasma diseases and their relationships with insect and plant hosts in Canadian horticultural and field crops. Canadian Entomol., 141: 425462.

Padovan, A., K. Gibb and D. Persley, 2000. Association of 'Candidatus Phytoplasma australiense' with green petal and lethal yellows diseases in strawberry. Plant Pathol., 49:362-369.

Sakila, S., M.B. Ahmed, U.K. Roy, M.K. Biswas, R. Karim, M.A. Razvy, M. Hossain, R. Islam and A. Hoque, 2007. Micropropagation of strawberry (Fragaria X ananassa Duch.) a newly introduced crop in Bangladesh. Am. Eurasian J. Sci. Res., 2(2):151-154.

Schneider, B., M.T. Cousin, S. Klinkong and E. Seemüller, 1995. Taxonomic relatedness and phylogenetic positions of phytoplasmas associated with diseases of faba bean, sunn hemp, sesame, soybean, and eggplant. J. Plant Dis. Prot., 102:225-232.

Singh, B., S. Sharma, G. Rani, V. Hallan, A.A. Zaidi, G.S. Virk and A. Nagpal, 2008. In vitro micrografting for production of Indian citrus ringspot virus (ICRSV)-free plants of kinnow mandarin (Citrus nobilis Lour $\times$ C. deliciosa Tenora). Plant Biotechnol. Rep., 2:137. 
Smith, S., R. Hilton and N. Frazier, 1970. Meristem culture for elimination of strawberry viruses. Hilgardia, 24(8):8-10.

Sofy, A.R., 2015. First molecular characterization of Strawberry vein banding Virus naturally spread in mixed infection with fruit phyllody phytoplasma in Egypt. Int. J. Virol. Mol. Biol., 4(2):23-36.

Verma, N., R. Ram, V. Hallan, K. Kumar and A.A. Zaidi, 2004. Production of Cucumber mosaic virusfree chrysanthemum by meristem tip culture. Crop. Prot., 23: 462-473.

Whitehouse, A.B., C.L. Govan, K.J. Hammond, D.J. Sargent and D.W. Simpson, 2011. Meristem culture for the elimination of the strawberry crown rot pathogen Phytophthora cactorum. J. Berry Res., 1:129-36. 